\title{
Do All Roads Lead to Rome? The Effect of the Decision-Making Logic on Business Model Change
}

\section{Lasse Torkkelî, Hanna Salojärvi², Liisa-Maija Sainio³, Sami Saarenketo 4}

\begin{abstract}
Business models and business model change have drawn increasing attention from both researchers and practitioners across various disciplines, including the domain of entrepreneurship. However, even though the importance of business model innovation as a driver of firm performance has been widely acknowledged, empirical studies explaining the business model change remain limited. This study contributes to prior research by examining the effects of effectual and causation-based decisionmaking logics on the degree of business model change in the context of small and medium-sized enterprises in Finland. The findings of hierarchical regression analysis show that both causation and effectuation-based logics have positive effects on business model change, thereby highlighting the need for both strategizing and seizing of opportunities in business model development.

Keywords: business model, decision-making, effectuation, causation, small and medium enterprises.
\end{abstract}

\section{INTRODUCTION}

Business models and business model change have intrigued both business researchers and practitioners in various fields, including the domain of entrepreneurship. Competition in today's business is increasingly determined by the ability of companies to innovate their business models: Competition between companies has been driven by technological oversupply (Christensen, 1997), and older companies in particular have been struggling to adapt to the

1 Lasse Torkkeli, Post-doctoral researcher, Ph.D., Lappeenranta University of Technology, School of Business and Management, P.O.Box 20, 53851, Lappeenranta, Finland, tel.: +358 40359 1740, e-mail: lasse.torkkeli@lut.fi.

2 Hanna Salojärvi, Associate Professor, Ph.D., Lappeenranta University of Technology, School of Business and Management, P.O.Box 20, 53851, Lappeenranta, Finland, tel..+358 40136 7966, e-mail: hanna.salojarvi@lut.fi.

3 Liisa-Maija Sainio, Professor, Ph.D., Lappeenranta University of Technology, School of Business and Management, P.O.Box 20, 53851, Lappeenranta, Finland, tel.:+358 40515 4944, e-mail: liisa-maija.sainio@lut.fi.

4 Sami Saarenketo, Professor, Ph.D., Lappeenranta University of Technology, School of Business and Management, P.O.Box 20, 53851, Lappeenranta, Finland, tel.:+358 50308 6181, e-mail: Sami.Saarenketo@lut.fi. 
accelerating cycle of product development (Nagle \& Golden, 2002). Indeed, product innovation may not suffice in evolving competition, due to pressures for cost reduction (MacMillan, 1998) and brand management (Gopalani \& Shick, 2011).

Conversely, innovating the business model, rather than specific products, can provide the solutions companies need to survive in the ever-evolving cycle of competition, due to the fact that business model innovation can improve the competitive position of the company in ways that traditional product innovation cannot (Amit \& Zott, 2012). Moreover, it can also result in beneficial adaptation of competitive strategy (Chesbrough \& Rosenbloom, 2002; Chesbrough, 2007) to account for the changing business environment, thus enabling companies to respond to those changes at the strategic level. In general, it is now acknowledged that business model innovation may complement or even outperform the role of product or process innovation in the success of firms (Amit \& Zott, 2012). Business model change may be incremental or radical in scope, triggered by either internal or external input. Business model innovation in itself may be considered as a dynamic capability (Mezger, 2014). Overall, however, there is still room for research elaborating on the firm-internal processes related to business model change and managing change in SMEs.

In this study, we examine how the decision-making logic in small and medium-sized enterprises (SMEs) comes to determine their business model change. In doing so, we differentiate between the influences of causal and effectuation-based logics, as defined by Sarasvathy (2001) and Chandler, DeTienne, McKelvie \& Mumford (2011). According to Sarasvathy (2001, p. 245) effectuation refers to processes that "take a set of means as given and focus on selecting between possible effects that can be created with that set of means" while causation refers to more planned strategic approach where an entrepreneur sets a particular goal and selects appropriate means to reach the goal. This type of study is timely and relevant due to several reasons.

Firstly, even though effectuation has presented a paradigm shift in understanding the entrepreneurial decision-making logic, until recently there have been only a few studies to empirically test the effectual logic (Perry et al., 2012). This is a noteworthy omission since, in addition to bricolage (Baker, Miner \& Eesley, 2003; Baker \& Nelson, 2005), effectuation is the most potent emerging theoretical perspective in entrepreneurship (Fisher, 2012).

Secondly, most of the empirical studies investigating the causationeffectuation dynamics in decision-making have been either conceptual or descriptive case studies (Perry, Chandler \& Markova, 2012) and have tended to focus on the individual entrepreneur, rather than the enterprise, as the unit of analysis (Bird \& Schjoedt, 2009; McMullen \& Shepherd, 2006). 
Yet, the paradigm shift in entrepreneurial decision-making facilitated by effectuation theory also has deep implications for management research at the organizational level, as management has traditionally been described by causation-based logic with the firm as the main unit of analysis (Drucker, 1998; Shane \& Venkataraman, 2000) - a view that is now being challenged by the rise of the effectuation theory. Moreover, even though Chandler et al. (2011) have recently validated a scale for effectuation, its further application has been lacking, particularly in the SME context.

Thirdly, in their literature review on studies examining the decisionmaking logic from the effectual point of view, Perry et al. (2012), while noting that research has neglected to highlight the relationships between variables, explicitly call for testing its effect on business model change.

Based on the research gaps identified above, it appears that more empirical research into the entrepreneurial decision-making logic is called for. We respond to the above-mentioned gaps by investigating the impact of effectual and causation-based logics on the strategic outcomes of SMEs in a measurable, quantitative research setting. The question of how the business model innovation process occurs is an interesting one, and by investigating how the type of decision-making logic impacts on the ability of an entrepreneurial company to exert change in its business models we are also further responding to the call for more research on the drivers of business model change.

This article continues as follows: First, we will present a review of the existing literature on the two main decision-making logics found prevalent in entrepreneurial companies - causation and effectuation-based logics. Next, we outline the potential linkages between the logics and the business model change. The following section introduces our research methodology. Finally, the results are illustrated, and we conclude by discussing their contributions and implications, while also highlighting the limitations of the present study and further research avenues provided by it.

\section{LITERATURE REVIEW}

\section{Decision-making logic: Causation and effectuation-based logics}

The traditional models of entrepreneurial decision-making have tended to align with those prevalent in strategic management, where firms try to predict future changes in their business environment, to create a formalized strategy in order to achieve the set goals, and to measure performance against those goals through actualized returns (Alvarez \& Barney, 2007). Sarasvathy (2001; 2008) has differentiated this causation-based logic from effectuation, by 
which entrepreneurs conversely tend to start with the means rather than the goals, to prefer the principle of affordable loss to optimized pre-strategizing, and to leverage contingencies rather than trying to predict them.

This view has been argued to better describe the nature of entrepreneurial opportunities, which consist of recognizing new ideas and inventions, beliefs, and actions (Sarasvathy, Dew, Velamuri \& Venkataraman, 2010). The perception of potential new business models and the subsequent innovation of business models would by extension be expected to fit into this view (Perry et al., 2012). That would imply a non-predictive strategy (Wiltbank, Dew, Read \& Sarasvathy, 2006), a logic that is in part contrast to the traditional views of organizational management based on formalized strategizing and trying to predict the future business environment (Porter, 1996).

Fisher (2012) provides a clear description of these differences in the decision-making logic, based on a literature review of the existing research on effectuation theory. He notes that a major distinguishing factor between the use of causal or effectual logic in entrepreneurship comes down to decision theory: i.e., decision-makers facing a measurable and/or predictable future tend to favor the former, whereas decision-makers dealing with an unpredictable environment and uncertainty may favor experimentation and iterative learning instead. McMullen and Shepherd (2006) also suggest that the extent of uncertainty lies at the root of entrepreneurial theorizing.

In addition, existing research has suggested that effectual thinking is associated with over-trust in entrepreneurs (Goel \& Karri, 2006) and that, even though new ventures tend to engage in more effectual decision-making compared to established firms (Dew, Read, Sarasvathy \& Wiltbank, 2008), effectual thinking can be prevalent in both types of firms (Wiltbank et al., 2009). In general, effectual logic tends to be associated with increased uncertainty in the market environment, the newness of the enterprise, and an increased likelihood of success for a given company (Sarasvathy 2001; 2008).

The underlying decision-making logic may come to determine practical product and organizational strategies: First, experimentation based on the affordable loss principle of effectuation may shorten product development cycles, resulting in companies conceptualized as "lean startups" (Blank, 2013; Ries, 2011). Companies embracing such mindset can speed up the product development process by pivoting and creating minimal viable products for testing (Ries, 2011). These methods are related to trial-and-error learning, which has been highlighted as an enabler of business model innovation (Sosna et al., 2011). Trial-and-error learning can also help link organizational routines to organizational schemata, thus helping them manage in changing environments (Rerup \& Feldman, 2011). However, so far we still do not have a clear view of how effectuation as a decision-making logic is linked 
to the differing capabilities of SMEs to innovate their business model; the investigation by Sosna et al. (2011) was conducted in a longitudinal single case setting, and thus a more comprehensive, cross-industry view into the phenomenon across different types of SMEs is still to be developed.

Effectual logic has been further highlighted in international entrepreneurship (Sarasvathy, Kumar, York \& Bhagavatula, 2014) in general, as well as been found to impact on the internationalization process (Kalinic, Sarasvathy \& Forza, 2014) and small-firm internationalization (Andersson, 2011; Harms \& Schiele, 2012; Nummela, Saarenketo, Jokela \& Loane, 2014; Schweizer, 2015) in particular. Recent studies have also found the effectual logic to be linked to the level of corporate R\&D (Brettel, Mauer, Engelen \& Küpper, 2012), to entrepreneurial exit strategy (DeTienne \& Chandler, 2010), and to increased entrepreneurial orientation (Mthanti \& Urban, 2014). However, despite the fact that its impact on corporate business models should be clarified (Perry et al., 2012), the dynamics of causal and effectual logics on the extent of business model change have not received prior research attention.

\section{Decision-making and business model change}

A business model describes the design or architecture of value creation and capture - a system of interdependent and interconnected activities determining the way of operation of a firm (Teece, 2010, Zott, Massa \& Amit, 2011). Lately, the concept has been widely used in various contexts and management areas ranging from strategy and technology management to entrepreneurship (for a thorough conceptual investigation, see e.g. Zott et al., 2011). In today's changing environmental and competitive conditions, the question of how to adapt and change the business model (Doz \& Kosonen, 2010) is of utmost relevance to companies. A growing body of research investigates the phenomenon of business model innovations from various viewpoints, such as capability (Achtenhagen, Melin \& Naldi, 2013), learning (Andries \& Debackere, 2013) and sustainability (Schaltegger, Lüdeke-Freund \& Hansen, 2012), but only a few empirical studies examine the connection of firm-level decision-making and business model change. Current literature provides some support for both the causation and the effectuation perspectives of decision-making in the context of business model change. Thus, we intend to present "both sides of the coin" for hypothesis testing in our exploratory empirical setting.

The need for business model change can arise as a response to either an internal or external opportunity or threat (Bucherer, Eisert \& Gassmann, 2012), followed by a process of analysis, design, implementation, and control. 
The degree of change may vary from small incremental business model adaptations to a more dramatic business model renewal (Achtenhagen et al., 2013) changing both the strategy and organization of the firm (Agarwal \& Helfat, 2009). The dynamic capabilities framework for sustainable enterprise performance by Teece (2007) consists of capacities to sense, seize, and transform opportunities. His construct of sensing market and technological opportunities is analytical and reflects a system of causal logic, followed by delineating a proper business model as part of the seizing construct. Similarly, Mezger (2014) identifies both technology and business model sensing as capabilities that precede seizing capabilities related to business model configuration and the advancement of business models. His description of business model sensing reflects causal logic supported by his empirical findings that firms with frequent, institutionalized processes to get e.g. formal and informal customer feedback on emerging business models and customer requirements were better able to generate and advance new business model ideas. Therefore, we hypothesize:

H1: The higher the level of causal logic in an SME, the bigger the change in its business model.

As a contrast to the traditional strategic planning processes, an emerging stream of literature (see e.g.: McGrath, 2010) argues that instead of thorough analysis processes, experimentation or trial-and-error-learning (Sosna, Trevinjo-Rodrigues \& Velamuri, 2010; Khanagha, Volderba \& Oshri, 2014) are the keys for business model change. Chesbrough (2010) argues that business model innovation is about managing change in an organization through the processes of experimentation, effectuation, and successful leadership. Especially as the entrepreneurial process of an SME can be considered to be a mechanism for continuous and rapid innovation, early-stage firms require business model experimentation to rapidly test the market and validate or reject the business opportunity. (Trimi \& Berbegal-Mirabent, 2012).

The proponents of effectuation processes argue that emergent opportunities typically lack rich data to justify corporate actions such as reframing the dominant logic of one's business model. In those situations, entrepreneurs do not analyze their environment but rather take actions that create new information and reveal latent possibilities regarding business model innovation (Chesbrough, 2010; Khanagha et al., 2014). Especially start-ups may favor this "pivoting" approach, where the new venture starts with quite imprecise facts about the opportunity at hand, followed by multiple stages of information gathering and trial-and-error attempts (Girotra and Netessine, 2014). Experimentation may also make business 
more dynamic compared with the analytical strategic approach: even though most experiments may fail, new designs cannot be found without failures (McGrath, 2010). Experimentation with business models may also take place outside the core business of the firm (Agarwal \& Helfat, 2009).

However, according to Doz and Kosonen (2010), experimentation activities may be hampered by organizational limitations. Existing business models tend to be rigid: the elements are tightly coupled as a system, and a possible modification attempt in the system creates tension that may prevent change. Organizational inertia combined with the limited resources of an SME may limit the possibilities for organizational change and innovation (Huang, Lai, Lin \& Chen, 2012). Thus, flexibility may be one of the preconditions for business model innovation and change. Flexibility is a leadership challenge: the success of previous business models may create a barrier to change existing asset configurations (Chesbrough, 2010). Thus, managers need to encourage a culture of strategic flexibility to challenge the blinders of the dominant logic that favors existing business models. Bock, Opsahl, George \& Gann (2012) examined the roles of organizational culture and structure with regard to strategic flexibility and business model innovation. They found out that organizations with a creative climate are more likely to achieve strategic flexibility in their business model innovation efforts. Based on the above discussion, we hypothesize:

H2: The higher the level of effectual logic in an SME, the bigger the change in its business model.

\section{RESEARCH METHODS}

\section{Sample and data collection}

A cross-industrial sample of small and medium-sized firms (10-250 employees) in Finland was used to test our hypotheses. The sample was drawn from the Amadeus database. A structured, online survey instrument was used for collecting the data during May-September, 2014. A total of 1,130 firms were identified and contacted by phone to ensure their eligibility and willingness to participate in the study. Eligibility was determined based on two criteria. First, the size of the firm had to be within the limits of 10-250 employees. Second, the respondents needed to have independency in terms of strategic decision-making. Because of this, for example the sub-branches and Finnish subsidiaries of foreign firms were excluded from the study. Thus, 78 firms were determined as non-eligible. In spite of numerous efforts, 306 firms were not reached. Furthermore, 311 firms were not willing or able to 
participate, mostly due to the lack of time. The link to the survey was sent immediately after the respondent agreed to participate in the study.

We used several incentives to increase the response rate. First, in order to encourage participation in the study we promised a summary report of the survey results. Second, anonymity and confidentiality were assured. Finally, the respondents were also given an opportunity to win an iPad in a draw after the data collection. A reminder to the non-respondents was sent two weeks later. As a result we received 148 usable questionnaires, which lead to a response rate of $14 \%(148 / 1052)$. The respondents were mainly CEOs ( $84 \%$ of the respondents) or other persons in knowledgeable key positions. Thus, the key informant approach was used in collecting the data.

Several actions were taken to control for possible methodological biases. A possible non-response bias was evaluated by comparing the early and late respondents based on the recommendations by Armstrong and Overton (1977). No significant differences between the two groups were found. The possibility of common method bias was recognized already at the beginning of the questionnaire design following the recommendations by Podsakoff, Mackenzie \& Lee, 2003 (2003). The predictor and criterion variables were separated proximally in the questionnaire and anonymity of the respondents during the data collection was assured. We also used Harman's one factor test to check for common method bias after collecting the data. No signs of a common factor underlying the data were found, thus, common method bias was not considered a problem.

\section{Measures}

To assess the degree of business model change we generated items that would reflect concrete changes in the actions of the firm over previous years. Five items describing the magnitude of change and concerning the activities of the firm in the upstream (changes in the type of suppliers used), downstream (changes in the customer base, customer value proposition, sales network), and internally (know-how of the personnel) loaded on a single factor. In order to measure the main independent variables, namely causation and effectuation, we adapted items from Chandler et al. (2011) and, in addition, generated a few items ourselves. In doing so, we followed the suggestion by Perry et al. (2012) to distinguish between effectuation and causation processes and to apply measures that are not contrasted as the total opposites of causation measures. A seven-point Likert scale ranging from totally disagree to totally agree was used to measure the main independent variables and the dependent variable. 


\section{Scale reliability and validity}

Principal component analysis with Varimax rotation was used to develop composite measures for the independent and dependent constructs. Items with low correlations or strong cross-loadings (over .4) were deleted. Five items describing the business model change loaded on a single factor with an eigenvalue greater than one. In terms of independent variables, the causation and effectuation items mainly adapted from Chandler et al. (2011) loaded on three different factors with an eigenvalue larger than one. Four causation items adapted from Chandler et al. (2011) describing the extent to which strategic vision and analytical approach guide the actions of the firm loaded on a single factor. Five effectuation items adapted from Chandler et al. (2011) and one self-generated item on the other hand loaded on two different factors. Three items adapted from Chandler et al. (2011) describing the degree of experimentation in the firms loaded on the first factor. This we decided to name experimentation.

Finally, two effectuation items describing organizational flexibility adapted from Chandler et al. (2011) loaded on the same factor with one selfdeveloped item. This factor was named organizational flexibility accordingly. In order to assess the discriminant validity of the scales, we conducted another principal component analysis with Varimax rotation by including all the items of the main independent variables concurrently in the analysis (see item loadings in Table 1). The internal consistency of the scales was examined by calculating the reliability coefficient values (Cronbach's alpha) for each construct (see Table 1). The subsequent values were 0.818 (business model change), 0.812 (causation), 0.812 (experimentation) and 0.733 (organizational flexibility). As all values were well above 0.70 , they were considered reliable (Nunnally, 1978).

\section{Control variables}

In addition to management and the decision-making style also other factors could have an effect on business model change. For example, the size and age of the firm could be related to the ability of the firm to renew its value proposition and change the business model. On the other hand, also internationalization could be related to business model change, as internationalization could bring along new opportunities that accelerate business model change (see e.g., Mainela, Puhakka \& Servais, 2014), with experimentation being essential for international new ventures as they try to optimize their business models for global markets (Zahra, 2005). Similarly, control variables should be added in conjunction with analysis on effectual logic (Perry et al., 2012). 
Table 1. Factor loadings

\begin{tabular}{|c|c|}
\hline Main constructs and items & Loadings \\
\hline \multicolumn{2}{|l|}{ Causation $(\alpha=.812)$} \\
\hline $\begin{array}{l}\text { We analyze long run opportunities and select what we think will provide the } \\
\text { best returns }\end{array}$ & .806 \\
\hline $\begin{array}{l}\text { We research and select target markets and do meaningful } \\
\text { competitive analysis }\end{array}$ & .779 \\
\hline We design and plan business strategies & .749 \\
\hline We organize and implement control processes to make sure we meet objectives & .785 \\
\hline \multicolumn{2}{|l|}{ Experimentation $(\alpha=.812)$} \\
\hline We experiment with different products and business models & .696 \\
\hline Our product/service concept is quite different from our original conception & .918 \\
\hline $\begin{array}{l}\text { We tried many different approaches, until we found a functional business } \\
\text { model }\end{array}$ & .868 \\
\hline \multicolumn{2}{|l|}{ Organizational flexibiliy ( $\alpha=.733)$} \\
\hline We evolve the business to evolve as opportunities emerge & .833 \\
\hline We are flexible and utilise all opportunities as they open up & .855 \\
\hline We avoid acting in ways that would restrict our flexibility and ability to adjust & .727 \\
\hline \multicolumn{2}{|l|}{ Business model change $(\alpha=.818)$} \\
\hline We have directed our products /services to entirely new types of customers & .754 \\
\hline Our personnel's knowledge base has significantly changed & .710 \\
\hline Our value proposition to customers has significantly changed & .820 \\
\hline We use very different subcontractors than before & .820 \\
\hline We have renewed our sales network & .730 \\
\hline
\end{tabular}

\section{ANALYSIS}

\section{Description of the sample}

The sample was cross-industrial with the main industrial fields being manufacturing (53\%) and construction (20\%). Other industries in the sample 
were for example electricity, gas, steam, and air conditioning supply (5\%) and water supply, sewerage, waste management, and remediation activities (5\%). The average age of the firms was 31 years (standard deviation 24, range 2-142 years). Of the firms, $70 \%$ had less than 50 employees, and the remaining $30 \%$ more than 50 but less than 250 employees. The average size of the firm measured by the number of employees was 48 employees ( $S D=46$, range 6-240).

\section{Hypotheses testing}

A linear hierarchical regression analysis was used for testing our hypotheses. Prior to conducting the analysis we checked for the normal distribution and possible multicollinearity. The normal probability plot of the standardized residuals and scatterplot were appropriate and no deviations from normality were found. Variance inflation factors (VIF) were all below the cut-off value 10 (Hair, Anderson, Tatham \& Black, 1998), with the highest being 1,250 . Thus, multicollinearity was not regarded as a problem. Mean values, standard deviations, and correlations between the variables are shown in Table 2 . As seen in the table, business model change correlated positively and statistically significantly with all of the potential determinants: the strongest $(p<0.01)$ were its correlations with causation $(0.52)$ and experimentation (0.61) variables, with the correlation coefficient of organizational flexibility being positive $(0.19)$ at the $5 \%$ risk level.

Therefore, the pre-requirements for hypotheses testing were fulfilled, as potentially all of the variables included in the hypothesis could be expected to have the hypothesized effect. As two constructs regarding effectuation logic emerged in the factor analysis, both constructs were used in the regression analysis. The internationalization control variable also correlated positively with business model change $(0.26, p<0.01)$, a development which could also be expected based on existing research on SME internationalization (Mainela et al., 2014; Zahra, 2005). The inter-correlations between the variables measuring the aspects of the decision-making logic were also overall positive and significant, which supports the notion by Chandler et al. (2011) that causal and effectual logics can by and large exist parallel to each other, rather than being the opposite ends of a single continuum.

The results of the hierarchical regression analysis are shown in Table 3 . We entered the variables into the analysis in two phases. The control variables, namely firm size and internationalization, were entered in the first phase and the main independent variables in the second phase. This allowed to detect the added variance explained by the independent variables over the control variables. 
Table 2. Means, standard deviations, and correlations

\begin{tabular}{|c|c|c|c|c|c|c|c|c|}
\hline & Variable & $\begin{array}{l}\text { Mean } \\
\text { (SD) }\end{array}$ & 1 & 2 & 3 & 4 & 5 & 6 \\
\hline 1. & Business model change & $\begin{array}{l}3.69 \\
(1.31)\end{array}$ & 1.000 & & & & & \\
\hline 2. & Internationalization & $\begin{array}{l}.62 \\
(.49)\end{array}$ & $.261 * *$ & 1.000 & & & & \\
\hline 3. & Firm age & $\begin{array}{l}31 \\
(24,07)\end{array}$ & .020 & $.153^{*}$ & 1.000 & & & \\
\hline 4. & $\begin{array}{l}\text { Firm size (number of } \\
\text { employees) }\end{array}$ & $\begin{array}{l}48 \\
(46.43)\end{array}$ & .134 & $.273 * *$ & $.247 * *$ & 1.000 & & \\
\hline 5. & Causation & $\begin{array}{l}4.63 \\
(1.15)\end{array}$ & $.523 * *$ & $.224 * *$ & .075 & $.248 * *$ & 1.000 & \\
\hline 6. & Experimentation & $\begin{array}{l}3.66 \\
(1.41)\end{array}$ & $.612^{* *}$ & $.193 *$ & .059 & .128 & $.328 * *$ & 1.000 \\
\hline 7. & $\begin{array}{l}\text { Organizational } \\
\text { flexibility }\end{array}$ & $\begin{array}{l}5.49 \\
(1.02)\end{array}$ & $.189 *$ & .034 & -.087 & .098 & $.249 * *$ & $.142 *$ \\
\hline
\end{tabular}

Significance ${ }^{*} p<.05,{ }^{* *} p<.01$

The results show firstly that of the control variables only internationalization had a positive effect on business model change. However, once the independent variables are added in the equation the positive effect of internationalization remains no longer significant. Of the independent variables, causation was found to be positively associated with business model change $(\beta=0.345, p<0.01)$. A highly significant positive relationship was also found between experimentation and business model change $(\beta=0.480, p<0.01)$. Contrary to our expectations, organizational flexibility was not related to business model change.

\section{Discussion AND CONCLUSIONS}

Our aim in this study was to investigate how the decision-making logic in small and medium-sized enterprises impacts on the extent of their business model change. In doing so, we expanded upon the nascent (Perry et al., 2012) paradigm of effectuation in entrepreneurship research and examined the traditional, causation-based logic parallel to the effectual one, in line with the model and suggestions by Chandler et al. (2011). In particular, the present study helps in extending the knowledge on the nature of the business model innovation from capabilities and learning perspectives (Achtenhagen et al., 2013; Andries \& Debackere, 2013) towards the overall decision-making logic practiced at the organizational level. 
Table 3. Results of hierarchical regression analysis

\begin{tabular}{lll}
\hline Dependent variable: Business model change & & \\
Variable & Model 1 & Model 2 \\
\hline Firm size & .075 & -.036 \\
Firm age & -.037 & -.039 \\
Internationalization & $.246^{* *}$ & .105 \\
Causation & & $.346^{* *}$ \\
Experimentation & & $.481^{* *}$ \\
Organizational flexibility & & .031 \\
R2 & .074 & .503 \\
Change in R2 & & $.430^{* *}$ \\
F & $3.571^{* *}$ & $22.269^{* *}$ \\
\hline
\end{tabular}

**Significant at .01 level (two-tailed)

*Significant at .05 level (two tailed)

In sum, our results revealed that both causation and effectuationbased logics are linked with increased levels of business model change, thus highlighting the need for both strategizing and seizing of opportunities in business model development. More specifically, we found that experimentation, but not organizational flexibility, is the kind of effectual logic needed for such a change. These results align with Dutt, Gwebu \& Wang, (2015) who found that entrepreneurial intentions in emerging industries may develop through both causation and effectuation-based logics, and with the notion of Chandler et al. (2011, p. 177): "entrepreneurs using an effectuation approach may try different approaches in the marketplace before settling on a business model." Similarly, Chesbrough (2010) emphasizes that effectuation creates actions based on the preliminary results of experiments and generates new data for further business model design. Our results extend these studies by further emphasizing the differences in how different types of effectual logic impact on such change and by providing empirical evidence of the linkage based on a survey of 148 Finnish SMEs.

The non-significant result on the impact of organizational flexibility is contrary to Doz and Kosonen (2010), Chesbrough (2010) and Bock et al. (2012), whose studies have highlighted the need for managers to promote a culture of flexibility in order to overcome the dominant logics in legacy business models. Even though our analysis showed positive correlations and coefficients between organizational flexibility and the extent of business model change in 
SMEs, we still found that the former did not determine the extent of the latter. One possible reason for this might be that SMEs tend to be agile organizations by nature, and thus the added value of striving for maximal flexibility does not provide an increased impetus for innovating one's business model compared to competitors. The high mean value of organizational flexibility in the present study (5.5 out of 7) would appear to support this notion. Overall, however, successful business model innovation appears to require that SMEs are ready to engage in not only formal pre-strategizing, but also experimenting with potentially suitable business models and being willing to take affordable risks as suitable market opportunities emerge.

We readily recognize several limitations in our study. One is that we did not control for the experience of the decision-maker, which Dew, Read, Sarasvathy \& Wiltbank, (2009) have noted to be a substantial differentiator in the type of logic applied. Similarly, Perry et al. (2012) have suggested a mixed methods approach to studying the impact of effectual logic, and ours was a cross-sectional survey analyzed through quantitative methods. Thus, the dynamics of effectual and causal logic could be examined in further detail in future studies. Potentially arising questions are, for instance: Does the importance of causal and effectual logics on business model change develop over time, as the company learns from its experimentation and consequently accounts for that learning in its market strategy? And does strategizing allow the company the justification and sufficient frames to experiment upon the affordable loss principle suggested by effectuation? In other words, a possible feedback loop between the two logics could be explored in more detail in a longitudinal setting.

Another limitation of the present study, and simultaneously a promising approach for future studies, is the fact that our analysis did not investigate contingency effects, e.g. how market or technological dynamism and uncertainty may influence the relationship between decision-making logic and innovation of business models. For instance, rapid technological change may require managers to avoid trying to predict technological trajectories and rely more heavily on effectuation-based decision-making (Dew, Sarasvathy, Read \& Wiltbank, 2008). In addition, the overall characteristics of the focal technology may further influence the process of selecting business models: Pries and Guild (2011) distinguish between legal protections, specialized complementary assets, commercial uncertainty and technological dynamism. While our empirical sample, covering a wide spectrum of industry sectors, was aimed at generalizing across SMEs in general, we acknowledge that industryspecific examination might yield further detail on these contingencies.

Moreover, we suggest that beyond the prevalent organizational culture (Bock et al., 2012), the national culture of origin may have an effect on the type and dynamics of the entrepreneurial decision-making logic. Hofstede's 
(1980) indices measure the different continuums on a set of traits in the national context, and it is possible that these cultural traits have several effects: For instance, the extent of uncertainty avoidance could determine how willing firms are to engage in experimentation in favor of formal prestrategizing; long-term orientation could have the opposite effect. In this sense, we also recognize the limitation of a single country context in the present study, although we are confident that these results could be to a certain extent generalizable across countries similar to Finland, i.e., small open economies where technology-intensive SMEs are the norm rather than the exception, countries such as Sweden, Denmark, and Ireland. Finally, as key informant approach was used in collecting the data, we call for further research that would cross-validate our findings by using multiple informants. The use of different respondents for predictor and criterion variables would also facilitate eliminating the risk of potential common method bias as suggested by Podsakoff et al. (2003)

To conclude, we still have a limited understanding of business model change in firms and how the various decision-making logics influence this change. To extend our model, future research could focus more on, for example, the role of entrepreneurial bricolage, i.e. "making do with what is at hand" (see: Baker \& Nelson, 2005), and thus provide an even richer portrait of why and how small entrepreneurial firms change their business models. Furthermore, our unexpected finding on the role of organizational flexibility brought about a need to further theorize and investigate this determinant. Finally, while focusing on the antecedents in this study, we should also scrutinize the impact and outcomes of business model change more thoroughly. For example, the question whether and how the change of business models leads to the growth and success of firms remains an intriguing topic for the future.

\section{References}

Achtenhagen, L., Melin, L., Naldi, L. (2013). Dynamics of Business Models - Strategizing, Critical Capabilities and Activities for Sustained Value Creation. Long Range Planning, 46(6), 427-442.

Agarwal, R., Helfat, C. (2009). Strategic Renewal of Organizations. Organization Science, 20(2), 281-293.

Amit, R., Zott, C. (2012). Creating Value Through Business Model Innovation. Sloan Management Review, 53(3), 41-49.

Andries, P., Debackere, K. (2013). Business Model Innovation: Propositions on the Appropriateness of Different Learning Approaches. Creativity and Innovation Management, 22(4), 337-358. 
Alvarez, S. A., Barney, J. B. (2007). Discovery and Creation: Alternative Theories of Entrepreneurial Action. Strategic Entrepreneurship Journal, 1(1-2), 11-26.

Andersson, S. (2011). International Entrepreneurship, Born Globals and the Theory of Effectuation. Journal of Small Business and Enterprise Development, 18(3), 627-643.

Armstrong, S., Overton, T.S. (1977). Estimating Non-response in Mailed Surveys. Journal of Marketing Research, 14(3), 396-402.

Baker, T., Miner, A. S., Eesley, D. T. (2003). Improvising Firms: Bricolage, Account Giving and Improvisational Competencies in the Founding Process. Research Policy, 32(2), 255-276.

Baker, T., Nelson, R. E. (2005). Creating Something from Nothing: Resource Construction through Entrepreneurial Bricolage. Administrative Science Quarterly, 50(3), 329-366.

Bird, B., Schjoedt, L. (2009). Entrepreneurial Behavior: Its Nature, Scope, Recent Research, and Agenda for Future Research. In: A. L. Carsrud, M. Brännback (Eds.), Understanding the Entrepreneurial Mind. Opening the Black Box (pp. 327-358). Dordrecht - Heidelberg - London - New York: Springer.

Blank, S. (2013). Why the Lean Start-up Changes Everything. Harvard Business Review, 91(5), 63-72.

Bock, A.J., Opsahl, T., George, G., Gann, D. M. (2012). The Effects of Culture and Structure on Strategic Flexibility During Business Model Innovation. Journal of Management Studies, 49(2), 279-305.

Brettel, M., Mauer, R., Engelen, A., Küpper, D. (2012). Corporate Effectuation: Entrepreneurial Action and its Impact on R\&D Project Performance. Journal of Business Venturing, 27(2), 167-184.

Bucherer, E., Eisert, U., Gassmann, O. (2012). Towards Systematic Business Model Innovation: Lessons from Product Innovation Management. Creativity and Innovation Management, 21(2), 183-198.

Chandler, G. N., DeTienne, D. R., McKelvie, A., Mumford, T. V. (2011). Causation and Effectuation Processes: A Validation Study. Journal of Business Venturing, 26(3), 375-390.

Chesbrough, H. (2007). Business Model Innovation: It's not Just about Technology Anymore. Strategy \& Leadership, 35(6), 12-17.

Chesbrough, H. (2010). Business Model Innovation: Opportunities and Barriers. Long Range Planning, 43(2-3), 354-363.

Chesbrough, H., Rosenbloom, R. S. (2002). The Role of the Business Model in Capturing Value from Innovation: Evidence from Xerox Corporation's Technology Spin-off Companies. Industrial and Corporate Change, 11(3), 529-555.

Christensen, C. (1997). Patterns in the Evolution of Product Competition. European Management Journal, 15(2), 117-127. 
DeTienne, D. R., Chandler, G. N. (2010). The Impact of Motivation and Causation and Effectuation Approaches on Exit Strategies. Frontiers of Entrepreneurship Research, 30(1), 1-13.

Dew, N., Read, S., Sarasvathy, S. D., Wiltbank, R. (2008). Outlines of a Behavioral Theory of the Entrepreneurial Firm. Journal of Economic Behavior \& Organization, 66(1), 37-59.

Dew, N., Read, S., Sarasvathy, S. D., Wiltbank, R. (2009). Effectual versus Predictive Logics in Entrepreneurial Decision-Making: Differences between Experts and Novices. Journal of Business Venturing, 24(4), 287309.

Dew, N., Sarasvathy, S. D., Read, S., Wiltbank, R. (2008). Immortal Firms in Mortal Markets? An Entrepreneurial Perspective on the "Innovator's Dilemma". European Journal of Innovation Management, 11(3), 313-329.

Doz, Y. L., Kosonen, M. (2010). Embedding Strategic Agility - A Leadership Agenda for Accelerating Business Model Renewal. Long Range Planning, 43(1-2), 370-382.

Dutta, D. K., Gwebu, K. L., Wang, J. (2015). Personal Innovativeness in Technology, Related Knowledge and Experience, and Entrepreneurial Intentions in Emerging Technology Industries: a Process of Causation or Effectuation? International Entrepreneurship and Management Journal, 11(3), 529-555.

Drucker, P. F. (1998). The Discipline of Innovation. Harvard business review, 76(6), 149-157.

Girotra, K., Netessine, S. (2014). Four Paths to Business Model Innovation. Harvard Business Review, 92(7-8), 96-103.

Goel, S., Karri, R. (2006). Entrepreneurs, Effectual Logic, and Over-Trust. Entrepreneurship Theory and Practice, 30(4), 477-493.

Gopalani, A., Shick, K. (2011). The Service-enabled Customer Experience: A Jump-start to Competitive Advantage. Journal of Business Strategy, $32(3), 4-12$.

Fisher, G. (2012). Effectuation, Causation, and Bricolage: a Behavioral Comparison of Emerging Theories in Entrepreneurship Research. Entrepreneurship Theory and Practice, 36(5), 1019-1051.

Hair, J. F., Anderson, R. E., Tatham, R. L., Black, W. (1998). Multivariate Data Analysis, 5th edition. New Jersey: Prentice Hall.

Harms, R., Schiele, H. (2012). Antecedents and Consequences of Effectuation and Causation in the International New Venture Creation Process. Journal of International Entrepreneurship, 10(2), 95-116.

Hofstede, G. (1980). Culture and Organizations. International Studies of Management \& Organization, 10(4), 15-41.

Huang, H. C., Lai, M. C., Lin, L. H., Chen, C. T. (2012). Overcoming Organizational Inertia to Strengthen Business Model Innovation - an Open Innovation Perspective. Journal of Organizational Change Management, 26(6), 9771002. 
Kalinic, I., Sarasvathy, S. D., Forza, C. (2014). Expect the Unexpected': Implications of Effectual Logic on the Internationalization Process. International Business Review, 23(3), 635-647.

Khanagha, S., Volderba, H., Oshri, I. (2014). Business Model Renewal and Ambidexterity: Structural Alteration and Strategy Formation Process during Transition to a Cloud Business Model. R\&D Management, 44(3), 322-340.

MacMillan, I. C. (1988). Controlling Competitive Dynamics by Taking Strategic Initiative. The Academy of Management Executive, 2(2), 111-118.

Mainela, T., Puhakka, V., Servais, P. (2014). The Concept of International Opportunity in International Entrepreneurship: A Review and a Research Agenda. International Journal of Management Reviews, 16(1), 105-129.

McGrath, R.G. (2010). Business Models: A Discovery Driven Approach. Long Range Planning, 43(2-3), 247-261.

McMullen, J. S., Shepherd, D. A. (2006). Entrepreneurial Action and the Role of Uncertainty in the Theory of the Entrepreneur. Academy of Management Review, 31(1), 132-152.

Mezger, F. (2014). Toward a Capability-based Conceptualization of Business Model Innovation: Insights from an Explorative Study. $R \&$ D Management, 44(5), 429-449.

Mthanti, T. S., Urban, B. (2014). Effectuation and Entrepreneurial Orientation in High-Technology Firms. Technology Analysis \& Strategic Management, 26(2), 121-133.

Nagle, T., Golden, W. (2009). An Examination of the Disruptive Innovation Paradox: The Application of the Innovators Dilemma to SME's. In: G. Dhillon, B. C. Stahl, R. Baskerville (Eds.), Information Systems - Creativity and Innovation in Small and Medium-Sized Enterprises (pp. 60-72). Berlin - Heidelberg - New York: Springer.

Nummela, N., Saarenketo, S., Jokela, P., Loane, S. (2014). Strategic DecisionMaking of a Born Global: A Comparative Study From Three Small Open Economies. Management International Review, 54(4), 527-550.

Nunnally, J. C. (1978). Psychometric Theory. New York: McGraw-Hill.

Perry, J. T., Chandler, G. N., Markova, G. (2012). Entrepreneurial Effectuation: a Review and Suggestions for Future Research. Entrepreneurship Theory and Practice, 36(4), 837-861.

Podsakoff, P. M., MacKenzie, S. B., Lee, J. Y. (2003). Common Method Biases in Behavioral Research: A Critical Review of the Literature and Recommended Remedies. Journal of Applied Psychology, 88(5), 879-903. Porter, M. E. (1996). What is Strategy?, Harvard Business Review, 74(6), 61-78. Pries, F., Guild, P. (2011). Commercializing Inventions Resulting from University Research: Analyzing the Impact of Technology Characteristics on Subsequent Business Models. Technovation, 31(4), 151-160.

Rerup, C., Feldman, M. S. (2011). Routines as a Source of Change in Organizational Schemata: The Role of Trial-and-Error Learning. Academy of Management Journal, 54(3), 577-610. 
Ries, E. (2011). The Lean Startup: How Today's Entrepreneurs Use Continuous Innovation to Create Radically Successful Businesses. London: Random House.

Sarasvathy, S. D. (2001). Causation and Effectuation: Toward a Theoretical Shift from Economic Inevitability to Entrepreneurial Contingency. Academy of Management Review, 26(2), 243-263.

Sarasvathy, S. D. (2008). Effectuation: Elements of Entrepreneurial Expertise. Cheltenham: Edward Elgar.

Sarasvathy, S. D., Dew, N., Velamuri, S. R., Venkataraman, S. (2010). Three Views of Entrepreneurial Opportunity. In: Z. J. Acd, D. B. Audretch (Eds.), Handbook of Entrepreneurship Research (pp. 77-96). New York: Springer.

Sarasvathy, S., Kumar, K., York, J. G., Bhagavatula, S. (2014). An Effectual Approach to International Entrepreneurship: Overlaps, Challenges, and Provocative Possibilities. Entrepreneurship Theory and Practice, 38(1), 71-93.

Schaltegger, S., Lüdeke-Freund, F., Hansen, E. G. (2012). Business Cases for Sustainability: the Role of Business Model Innovation for Corporate Sustainability. International Journal of Innovation and Sustainable Development, 6(2), 95-119.

Schweizer, R. (2015). Decision-making During Small and Medium-sized Enterprises' Internationalisation-effectuation vs. Causation. Journal for International Business and Entrepreneurship Development, 8(1), 22-41.

Shane, S., Venkataraman, S. (2000). The Promise of Entrepreneurship as a Field of Research. Academy of Management Review, 25(1), 217-226.

Sosna, M., Trevinjo-Rodrigues, R. N., Velamuri, S. R. (2010). Business Model Innovation Through Trial-and-Error Learning: The Naturhouse Case. Long Range Planning, 43(2-3), 383-407.

Teece, D. J. (2007). Explicating Dynamic Capabilities: the Nature and Microfoundations of (Sustainable) Enterprise Performance. Strategic Management Journal, 28(13), 1319-1350.

Teece, D.J. (2010). Business Models, Business Strategy and Innovation. Long Range Planning, 43(2-3), 172-194.

Trimi, S., Berbegal-Mirabent, J. (2012). Business Model Innovation in Entrepreneurship. International Entrepreneurship Management Journal, 8(4), 449-465.

Wiltbank, R., Read, S., Dew, N., Sarasvathy, S. D. (2009). Prediction and Control Under Uncertainty: Outcomes in Angel Investing. Journal of Business Venturing, 24(2), 116-133.

Wiltbank, R., Dew, N., Read, S., Sarasvathy, S. D. (2006). What to Do Next? The Case for Non-Predictive Strategy. Strategic Management Journal, 27(10), 981-998.

Zahra, S. A. (2005). A Theory of International New Ventures: A Decade of Research. Journal of International Business Studies, 36(1), 20-28.

Zott, C., Massa, L. Amit, R. (2011). The Business Model: Recent Developments and Future Research. Journal of Management, 37(4), 1019-1042. 


\section{Biographical notes}

Lasse Torkkeli is a post-doctoral researcher at the School of Business and Management of the Lappeenranta University of Technology, Finland. His research interests include: SME internationalization, business networks, organizational capabilities and competencies, and business-to-business interaction. He has previously published among others in "Journal of International Entrepreneurship" and "European Management Journal".

Hanna Salojärvi is an associate professor at the School of Business and Management of the Lappeenranta University of Technology. Her main research interests include: customer relationships, customer knowledge management and strategic orientations. She has published on these issues for example in "Industrial Marketing Management" and "European Journal of Marketing".

Liisa-Maija Sainio is a professor at the School of Business and Management of the Lappeenranta University of Technology. Her research interests include radical innovations, business models and customer knowledge processing. She has published among others in "Technovation", "Technological Forecasting and Social Change", and "R\&D Management".

Sami Saarenketo is a professor of International Marketing at the School of Business and Management of the Lappeenranta University of Technology, Finland. His primary areas of research interest are international marketing and entrepreneurship in technology-based small firms. He has published on these issues among others in "Journal of World Business", "International Business Review", "Management International Review", "European Journal of Marketing", and "Journal of International Entrepreneurship".

\section{Abstrakt (in Polish)}

Modele biznesowe i zmiana modelu biznesowego przyciqga rosnq̨a uwagę zarówno naukowców i praktyków z różnych dziedzin, $w$ tym $w$ dziedzinie przedsiębiorczości. Jednak, chociaż znaczenie innowacyjnego modelu biznesowego jako siły napędowej przedsiębiorstwa jest powszechnie uznawane, badań empirycznych wyjaśniajqce zmianę modelu biznesowego jest ciagle niewiele. Ta praca wnosi wkład we wcześniejsze badania, analizujqc skutki stosowania logiki podejmowania decyzji, opartej na zróżnicowanych zasadach wprowadzania w życie i przyczynowości, na stopień zmian modelu biznesowego $w$ kontekście małych i średnich przedsiębiorstw $w$ Finlandii. Wyniki hierarchicznej analizy regresji pokazujq, że zarówno obie logiki maja pozytywny wpływ na zmianę modelu biznesowego, podkreślajq̨ $w$ ten sposób zarówno konieczność obrania strategii i wykorzystania możliwości w celu rozwijania modelu biznesowego.

Słowa kluczowe: model biznesowy, podejmowanie decyzji, wprowadzanie w życie, przyczynowość, małe i średnie przedsiębiorstwa. 